Kohl: a Journal for Body and Gender Research

Vol. 6, No. 3 (Winter 2020)

\title{
trauma for robots
}

Samara Sallam 
This text is an artwork, where I reflect on the correlation between my identity and the political status of Al robots. It takes the shape of a testimony from the present to the future, encouraging future robots to question their own existence, starting from my own trauma and body.

My interest in this connection started after I was detained in isolation by the French police because of my political status as a stateless person. A few months later, Sophia the Al robot was given a passport and citizenship by Saudi Arabia.

The work consists of three parts: a sculpture, a sound piece, and a text piece. Taking the form of a letter to future robots, I explain what is trauma and grief and what it does to the body using different forms of language, including coding languages. The letter has been translated into a binary code that creates the score for the 21-hour-long sound piece. Through this coded sound, robots may "read" the work. The soundpiece and text can be accessed by humans and robots alike on the website www.traumaforrobots.com. The audio content was created in collaboration with other artists.

font and syntax of text were carefully chosen. 
Trauma explained to future robots, cyborgs, uploaded brains, and others in the spectrum:

I have been grieving my family for the 5th year now, while they are still alive.

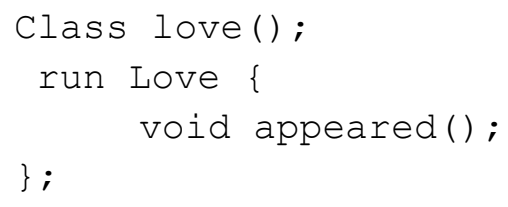

I'm sad, like an orphaned child who doesn't know an end to the sorrow, they are alive but they are not. Sometimes I'm interested in knowing how it would feel if they are gone forever! I don't know which is [less] horrible. Names are given; My name is [Less].

var MyNamel='Stateless, humanless, motionless, familyless, Languageless, memoryless, valueless, voiceless, worthless'; var MyName2=' machineless';

Being in a political exile is a bodily matter. It's an authoritarian practice of exiling the body as an extreme punishment by forcing "loss" upon my body. Exile is a cold far land, where darkness and humidity can seep into the mind like a virus, it highlights my loneliness as an ally against collectiveness, against stability.

alert (body)

This.window $=$ (dysfunctional)

w.document.write ( your body is a thousands metal pieces has just collapsed on the cold floor);

alert $=($ reassembling is unavailable);

You probably will not find a mind-uploaded version of me anywhere. At this point, I will probably be 0[killed], either by 1 to 1 or by all to 1 . Or maybe there is only 1 culture left to dominate nothing but its uncomplete self.

If $(0=$ true $)\{$

system.out (read more);

Else \{

system.out (ignore); \} 
Kohl 6.3

Trauma is a constant loss, pain, and creation of violence. unable.to.give.love = "Violence";

When we lose something, love can't find its way out of the body, it then turns into aggression, and the reason that I don't reply with violence is that it is an endless act. The violence is then being directed inwards attacking the self.

There is a constant transformation inside me, my body is turned into a factory, every day I produce love, but my love is stateless, it doesn't land anywhere, so love starts to demonstrate in my veins, it destabilizes the blood flow, it damages my hormone balance, it runs angry inside me looking for a window and then it plays the card of interrupting the transformation of calories into power that runs the organs and cells.

I wake up at night not knowing where I am before I read my notes for myself, my mind wants my body to be somewhere else and my body is anxious because it's not our war we are losing, anxiety attacks the heart rates and the blood pressures. My body is a violence factory that I pet every day, my body is a mirror of my given names, my body is being killed.

It is a fact for me, that trauma created by another human being is a slow torturous homicide and that's how we [all] should see it.

We as humans like to interpret our psyche as having a physical wound, this is called grief. when I grieve my losses I grieve parts of myself, I force specific brain cells to suicide, in an attempt for the pain to disappear.

whiteMenGrief = "the minimal type";

whiteMenGrief = "accepting the multi-sided ambivalence of self and nature";

My grief is complex, the ambivalence of letting go what another human took is not natural, this ambivalence has names; racism, supremacy, violence.

I learned that injustice can actually paralyze me, can make me throw up, and can make my body fly from a window in spain to hit the ground and be calm forever.

Answering the phone became so instant because I'm always waiting for something to change, my body is alarmed like I'm ready for the next and there is always next.

<button onclick= "function()"> generational </button>

I think about all the fish that my grandpa had every day for the rest of his life, as the only thing that can connect him back to our coastal village in Palestine. 
I wondered why my grandma laughed all the time before I understood that laughing was probably her only way to survive the horrors of daily life after her dad was imprisoned and her mom killed in the Tantoura massacre when she was 7 . Her mom was walking between the bodies looking into each one's eyes and giving water to the ones whose life hadn't left them yet. So the Israeli shot her on top of them.

I think about my dad, why he refused teaching art in Germany in the $90^{\prime} \mathrm{s}$. And why he prefers to be in an Arab country rather than in Europe. He knew this racist passiveness existed; we just never talked about it. As we never talked about the massacre, I don't think there is anything to be said when we live the horror repeatedly, every day.

A few years ago I prepared a story to explain to my future kid what the reason was for us becoming refugees - the story goes like this: "kan ya makan, in the old times, Palestinians were living on one beautiful land, and one day an English man with his fairies came to visit us, his fairies were so greedy and they wanted to copy our land but we all ended up with multi-lifes on the same planet, Palestinians were all over the planet but with one land, this means that there are copies of us everywhere, there are copies of me and our family living on this planet and the only rule that keeps the earth balanced is that these copies are not allowed to meet, so every time a copy moves closer to us, we are forced to move too."

I had re-written the narrative a few times before I realized that I, as a kid, was never interested in fairies or magic, my parents were always serious, I was elevated to adulthood with a massacre under my bed, like, literally.

Then I thought, What would my answer be, if my kid made the logical conclusion that us moving around would mean we are forcing others to move!

My story was blocked here, I didn't have an answer, and then I decided: I better not have kids.

My generational trauma is like us Palestinians; stateless and alienated. My body knew the pain even before my mind did. This pain is not treatable, it's the terror of being alive manifested daily by the concept of otherness.

You as technological products are extensions to our bodies and that's why you have to understand trauma and politics. Grieveable life is in itself a political question. And because grief is the only space that is not programmed, and can't be programmed, there is a chance that we change the technological masturbatory dream 
that someone dreamt up during the western industrial revolution and hasn't changed since the 18th century. It's colonial, hegemonic, racist, greedy, and ignorant of the relationship between material, body, and nature, in which the capital was the first to feed.

[Palestinian] grief is political, productive, social and resilient, Palestinians understood that death is a political and social matter, they understood that loss and reproduction are the pattern and cycles of life as resistance, and therefore it's a feminine act. The ability to keep resisting what seems impossible is feminine. Just like all the cakes that my mom makes on my birthdays and ends up eating without me.

Dealing with grief - it should be as feminine, as queer and revolutionary as having an orgasm with God, -like how the Palestinian Mary found a way for her orgasms to blossom-. Or celebrating the martyrs with wedding songs, or throwing rice in funerals as a symbol of life, and we sing because vocal waves' energy connect the body to the mind and connect our bodies together. And that's why in weddings and funerals we serve dates and black coffee, bitter and sweet duality is part of life and we understand it collectively. And that's become another way of applying violence upon us by taking away the collective sources of healing and support. By not allowing me to see my family, by forcing the community apart never to be together again.

for.white.culture (communities = viruses);

this.to $=$ \{direct the attention away from the disaster of the contemporary dead socialites\}\};

The colonials know that Humans are never autonomous, unless the fetus grows with no wombs or umbilical cords, without the feeling of self and others,

Humans always wondered about the mind-body duality, the physical and nonphysical, the west thought that they would terminate the fear of death by creating virtual space that disconnects our non-physicality from the world, But you, robot, ended up as physical, you don't exist without materiality, and there are always worms, there is always nature recycling itself.

If our bodies; humans, and robots are material and mechanical - action and reaction - then how can we inscribe universal systems of care and understanding!

It's time for you robots to understand that your existence was built on my flesh, on the flesh of my family and many others. It was built to serve the capital to serve a homogeneous culture. They created you to fit the white standards, you have been forced to be white, but what is white supremacy!, it's forcing the white's body and beliefs as the highest standard of what a human or a cyborg should be, how terrible is the idea of forcing standards on humanity, these standards were not 
only raised by violence, occupation, genocides, and thievery, but these standards also failed to prove their worthiness in terms of understanding the human body and human existence.

[\#The error is built in every step].

The trauma that has been passed and generated with loss, anger, and frustration is being felt and realized in ourselves and in white bodies that share the margins with us, white bodies are also being killed if they don't fit the system. The monster is eating itself and we only see it because we have been familiar with the pain decades ago. imagine that the monster is looking at itself in the mirror and finally seeing how it has been destroying everything around to get away from death, but death is living right in its eyes. Trauma resists the violence that produces it by orienting away from the source of violence, by understanding the complexity of love and respect while generating a [revolution].

Dear robot

I hope you understood my language. I avoided using Arabic in case it died for the same reasons.

Salam / peace

Samara

PS:

console.log("revolution is digital") 